\title{
The Influence of Producer Service Industry Agglomeration on Industrial Structure Upgrading:Empirical Analysis Based on Threshold Model
}

\author{
Huifen $\mathrm{Wu}^{1}$ \\ ${ }^{1}$ School of Economics and Management, Lanzhou University of Technology, Lanzhou, Gansu ,730050
}

\begin{abstract}
Absrtact: This paper selects the panel data of 30 provinces and cities in China from 2009 to 2017, and uses the threshold effect model to investigate the non-linear relationship between producer services agglomeration and industrial structure upgrading by taking the agglomeration degree of producer services lagging one year as the threshold variable. The results show that the effect of producer services agglomeration on industrial structure upgrading shows an inverted "U" nonlinear relationship, that is, there is an optimal agglomeration level, and the agglomeration effect has a lag.
\end{abstract}

\section{Introduction}

At present, China's economy has changed from the stage of high-speed growth to the stage of high-quality development. It is in the key period of changing the mode of development, optimizing the economic structure and transforming the power of growth. The optimization and upgrading of industrial structure is the key link and core of the transformation of economic kinetic energy. As China's economy has gradually changed from industrialization to industrialization, the role of producer services in economic development has shifted accordingly from "lubricant" to "propeller". Relying on the agglomeration of producer services to promote industrial optimization and upgrading, economic quality and efficiency has become an important way to achieve high-quality development in various regions. Therefore, how to give full play to the role of agglomeration externality in promoting industrial structure upgrading with the help of producer service industry agglomeration?

\section{Literature review}

Michaelsetal(2012) points out that economic agglomeration is beneficial to the specialization of division of labor and the continuous extension of industrial chain to provide power for industrial

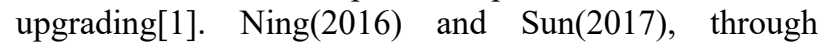
empirical research, it is found that producer services agglomeration has a significant positive impact on industrial structure optimization and upgrading[2-3]. However, Xia(2019) believe that China's producer services development is far from enough, and the concentration level in most regions is relatively low, which does not promote higher productivity in manufacturing[4]. The $\mathrm{Yu}(2019)$ points out that producer services agglomeration mainly promotes industrial structure upgrading through Porter externalities, while producer services MAR externalities and Jacobs externalities have a significant inhibitory effect on industrial structure upgrading[5].

To sum up, the impact of producer service agglomeration on industrial structure upgrading is still controversial. The existing literature only emphasizes the linear relationship between the agglomeration of producer services and the upgrading of industrial structure. However, agglomeration economy often has two sides, which makes it difficult for them to reach a consistent conclusion. Therefore, on the basis of previous studies, this paper empirically investigates the nonlinear relationship between producer service agglomeration and industrial structure upgrading by using threshold regression model.

\section{Model Construction and Variables Description}

\subsection{Model Building}

For verifying the nonlinear relationship between producer service agglomeration and industrial structure upgrading, this paper studies the threshold regression model proposed by Hansen(1999). At the same time, considering the lag of agglomeration effect, this paper 
introduces the agglomeration index of lag period as threshold variable. Model 1 is set to:

$$
\begin{aligned}
& \operatorname{lnins}_{i t}=c+\beta_{1} \ln _{\operatorname{lng}}\left\{\ln a g g_{i, t-1} \leq \gamma\right\}+ \\
& \beta_{2} \ln a g g_{i t}\left\{\ln a g g_{i, t-1}>\gamma\right\}+\beta_{3} \ln f d i_{i t}+ \\
& \beta_{4} \operatorname{lnhcl_{t}}+\beta_{5} \ln \operatorname{mart}_{t}+\beta_{6} \operatorname{lngov_{it}}+\varepsilon_{i t}
\end{aligned}
$$

\subsection{Variant description}

(1) Explained variable. Industrial structure upgrading Index (ins): this paper uses the ratio of tertiary industry added value to secondary industry added value to measure industrial structure upgrading.

(2) Explain variable. Productive service agglomeration (agg): this index is measured by location entropy. The formula is as follows:

$$
\operatorname{Iagg}=\frac{I_{i t}}{I_{t}} / \frac{P_{i t}}{P_{t}}
$$

Among them, Iit indicates the employment of producer services during $t$ period in i city; Pit indicates the employment during $\mathrm{t}$ period in i city;

(3) Control variables. Foreign direct investment (fdi): is according to the ratio of foreign direct investment to GDP, the amount of foreign direct investment should be converted according to the average value of RMB to the US dollar over the past year; The level of human capital (hcl): the population over 6 years of age in each province and city is divided into five levels: illiterate semi-literate, primary, junior high, senior high, junior college and above. The average length of schooling for each grade corresponds to $0,6,9,12$ and 16 years respectively. Then, according to the proportion of each education level in the population as the weight, the average educational years of each region are calculated; The degree of marketization (mart): measured by the market-oriented index in China's report on the market-oriented index of provinces; The strength of government support (gov): the proportion of government R\&D expenditure to local fiscal expenditure.

\subsection{Data description}

This paper selects the relevant data of 30 provinces and cities in China from 2009 to 2017 for research (not including Tibet). There are five categories as Productive services, such as "transportation, warehousing and postal services "," information transmission, computer services and software industry "," financial industry "," leasing and commercial services "," scientific research, technical services and geological exploration industry". The data are mainly derived from the Statistical Yearbook of China, the Statistical Yearbook of China's Science and Technology, and the local statistical yearbooks of provinces and cities. The missing data of individual samples were supplemented by interpolation. Table 1 gives the descriptive statistics.

Table 1. Descriptive statistics for variables

\begin{tabular}{ccccccc}
\hline Variable name & $\begin{array}{c}\text { Symbol } \\
\text { symbol }\end{array}$ & $\begin{array}{c}\text { Sample } \\
\text { size }\end{array}$ & Mean & $\begin{array}{c}\text { Standard } \\
\text { deviation }\end{array}$ & $\begin{array}{c}\text { Minimum } \\
\text { value }\end{array}$ & $\begin{array}{c}\text { Maximum } \\
\text { value }\end{array}$ \\
\hline $\begin{array}{c}\text { Industrial structure } \\
\text { upgrading index }\end{array}$ & $\operatorname{lnins}$ & 270 & 0.0746 & 0.3751 & -0.6405 & 1.5880 \\
$\begin{array}{c}\text { Concentration of } \\
\text { producer services }\end{array}$ & lnagg & 270 & -0.0014 & 0.5942 & -0.7874 & 2.2735 \\
Foreign direct investment & $\operatorname{lnfdi}$ & 270 & -4.3006 & 1.0324 & -7.9889 & -2.5021 \\
$\quad$ Human capital & $\operatorname{lnhcl}$ & 270 & 2.1971 & 0.0953 & -1.9323 & -2.5259 \\
Market level & lnmart & 270 & 1.8661 & 0.2605 & 1.1817 & 2.3312 \\
Government support & lngov & 270 & -4.4189 & 0.8526 & -5.9540 & -1.7503 \\
\hline
\end{tabular}

\section{Analysis of results}

\subsection{Threshold effects test}

Stata 16.0 statistical software is used to test the threshold effect. By taking the agglomeration level of the previous period as the threshold variable and setting up 300 self-sampling tests, the $\mathrm{F}$ value of the threshold test and the corresponding critical value, threshold estimate value and confidence interval are obtained. The results are shown in Table 2. The results of threshold effect test show that the influence of producer service agglomeration on industrial structure upgrading has passed the single threshold test of agglomeration level in the previous period, and the threshold value is 0.1056 . To a certain extent, this shows two points: firstly, the threshold effect of producer services agglomeration on industrial structure upgrading is widespread, and there is a single threshold, that is, both of them show nonlinear characteristics; Secondly, the influence of producer service agglomeration on industrial structure upgrading is greatly influenced by its own lagging variables, that is, agglomeration effect is lagging. 
Table 2. Results of self-sampling test and threshold estimation of threshold effect

\begin{tabular}{|c|c|c|c|c|c|c|c|}
\hline \multirow[t]{2}{*}{ Model } & \multirow{2}{*}{$\begin{array}{l}\text { Type of } \\
\text { threshold }\end{array}$} & \multirow{2}{*}{ F value } & \multicolumn{3}{|c|}{ Critical value } & \multirow{2}{*}{$\begin{array}{l}\text { threshold } \\
\text { value }\end{array}$} & \multirow{2}{*}{$\begin{array}{c}95 \% \\
\text { confidence } \\
\text { Interval }\end{array}$} \\
\hline & & & $10 \%$ & $5 \%$ & $1 \%$ & & \\
\hline Model & Single threshold & $25.52 *(0.0567)$ & 20.9247 & 25.9831 & 29.6944 & 0.1056 & {$[0.0894,0.1085]$} \\
\hline 1 & Double threshold & $10.18(0.4867)$ & 19.5261 & 23.3803 & 29.9881 & - & - \\
\hline
\end{tabular}

Note: Figures in parentheses are $\mathrm{p}$ values $; * * * * *, *$ represent significant levels of $1 \%, 5 \%$, and $10 \%$, respectively.

\subsection{Threshold regression analysis}

The regression results in Table 3 show that the impact of producer services agglomeration on the upgrading of industrial structure presents an inverted U-shaped relationship. When the level of agglomeration in the previous period is lower than the threshold value, the scale effect of agglomeration plays a leading role and is beneficial to the upgrading of industrial structure as many enterprises gather in a region. However, as the degree of agglomeration deepens, after the threshold is crossed, the crowding effect of agglomeration begins to become prominent. The agglomeration of producer services is no longer conducive to the upgrading of industrial structure due to the crowding effect brought by excessive industrial agglomeration.

In terms of control variables, human capital level and marketization level have significant positive promoting effects on the upgrading of industrial structure, which indicates that human capital is the core resource to promote the upgrading of industrial structure, and it is of great significance for the upgrading of industrial structure to give full play to the market competitive advantage. The promotion effect of government support on industrial structure upgrading is not obvious. It shows that the government plays an important role in economic development, but its operation efficiency is not high; Foreign direct investment hinders the upgrading of industrial structure. It shows that the proportion of fdi in GDP is small, and China may even fall into the "comparative advantage trap", which will have a negative effect on the upgrading of industrial structure.

Table 3. Results of threshold regression and robustness test

\begin{tabular}{cc}
\hline Variable & Model 1 \\
\hline $\ln$ Coagg & $0.3583^{* *}$ \\
$\left(\ln\right.$ Coagg $\left._{t-1} \leq \gamma\right)$ & $(2.16)$ \\
$\ln$ Coagg & $-0.4243^{* *}$ \\
$(\ln$ Coagg & $(-2.07)$ \\
$\operatorname{lnfdi}$ & -0.0043 \\
& $(-0.08)$ \\
$\operatorname{lnhcl}$ & $1.2215^{* * *}$ \\
& $(3.57)$ \\
$\operatorname{lnmart}$ & $0.7595^{* * *}$ \\
& $(7.05)$ \\
$\operatorname{lngov}$ & 0.0398 \\
& $(0.47)$ \\
-cons & $-3.6620^{* * *}$ \\
\multicolumn{2}{c}{$(-5.89)$} \\
Note: Figures in parentheses are t values $; * * * * * *$ represent significant
\end{tabular}

\section{Conclusions and Suggestion}

Based on the provincial panel data of 2009-2017 in China, this paper empirically investigates the nonlinear influence of producer service agglomeration on industrial structure upgrading by constructing panel threshold model. Through analysis, the following conclusions are drawn:

The effect of producer services agglomeration on the upgrading of industrial structure shows an inverted U-shaped nonlinear relationship. There is an optimal agglomeration level in producer service industry agglomeration. When the optimal threshold is crossed, the scale effect of agglomeration will be transformed into crowding effect, and the influence on industrial structure upgrading will change from positive to negative. In addition, the impact of producer service agglomeration on industrial structure upgrading is greatly affected by the level of agglomeration in the previous period, that is, the exertion of industrial agglomeration effect is lagging behind to a certain extent.

The above conclusions provide us with some enlightenment. When promoting the upgrading of China's industrial structure with the help of producer service agglomeration, we must remember to fall into the misunderstanding of blindly increasing (reducing) agglomeration degree.

For regions where producer services are in a low agglomeration area, industrial agglomeration is positively related to the upgrading of industrial structure. The government should take appropriate measures to expand the scale of industrial agglomeration and promote the spatial agglomeration of industries in order to obtain agglomeration advantages. However, when the agglomeration level of regional producer services exceeds the threshold value, industrial agglomeration is negatively correlated with the upgrading of industrial structure. The government should control the scale of industrial agglomeration and reduce the degree of spatial agglomeration to reduce the crowding effect caused by excessive industrial agglomeration.

\section{References:}

1. Michaels G ,F Rauch,Redding S .Urbanisation and structural transformation[J]. LSE Research Online Documents on Economics,2012,127(2):535-586.

2. Ning H ,Zhou X W ,School I B ,et al.Sub Producer Services Agglomeration and Industrial Structure Upgrading An Empirical Analysis of Provincial Economic Data[J]. Journal of Northwest University 
(Philophy and Social Sciences Edition),2016,046(004):94-99.

3. Sun C ,Zeng Q .Can Producer Services Agglomeration Promote China's Industrial Structure Optimization and Upgrading? The Empirical Test Based on the Inter-provincial Panel Data from 2005to 2013.ence and Technology Management Research,2017,037(001):105-110.

4. Xia L .Research on the Influence of Productive Service Industry Agglomeration on Manufacturing Productivity Based on Panel Model[J]. Journal of Hunan University of Finance and Economics,2019,035(003):67-75.

5. $\mathrm{Yu} \mathrm{B}$,Economics S O ,University Z G .How Does Producer Service Industry Agglomeration Promote Industrial Upgrading? An Empirical Analysis Based on Agglomeration Externality and Urban Scale Constraints.Comparative Economic \&Social Systems,2019,000(002):30-43.:1 